\title{
Tonsawang Language Speech Acts in Traditional Medicine
}

\author{
$1^{\text {st }}$ Ferdy Dj Rorong \\ Japanese Education Department \\ Universitas Negeri Manado \\ Manado, Indonesia \\ ferdy_rorong@yahoo.com \\ $4^{\text {th }}$ Helena Pandi \\ Japanese Education Department \\ Universitas Negeri Manado \\ Manado, Indonesia \\ helena_pandi@unima.ac.id
}

\author{
$2^{\text {nd }}$ Sherly Lensun \\ Japanese Education Department \\ Universitas Negeri Manado \\ Manado, Indonesia \\ sherlylensun@unima.ac.id \\ $5^{\text {th }}$ Fince Leny Sambeka \\ Japanese Language Department \\ Universitas Negeri Manado \\ Manado, Indonesia \\ fincesambeka@gmail.com
}

\author{
$3^{\text {rd }}$ Amelia Gladys Sompotan \\ Japanese Education Department \\ Universitas Negeri Manado \\ Manado, Indonesia
}

\author{
$6^{\text {th }}$ Susanti Aror \\ Japanese Education Department \\ Universitas Negeri Manado \\ Manado, Indonesia \\ Susantiaror78@gmail.com
}

\begin{abstract}
The vocabulary system in the concept of health that reflected in the language and culture of Tonsawang community shows the different characteristics that are different from the language and other cultures of the community. Identification of the types of disease will result in the names of disease in lexical form or word or phrase, sentence, or in short descriptive form which can be described through Tonsawang language. The problem that needs to be solves in this research revolves identifying the types of diseases.. Tonsawang community who live in Tombatu District has its own language, which is Tonsawang Language, however its culture is part of Minahasa Culture. In the Tonsawang community live and develop social systems and culture that maintained by its members. Tonsawang Language as well as other sub-ethnic languages in Minahasa, seems to be no longer inherited to children, so the language is feared to be extinct because in the language recorded traditional cultures, so the traditional culture is feared to changed, is also no exception in the system of Traditional Medicine. The formulation of the problem in this study covered three things, namely the system of disease according to Tonsawang Language, etiology of disease according to the belief of Tonsawang community, and the traditional system of medicine in Tonsawang community. The method used in this study was descriptive qualitative method and analysis as suggested in the ethnoscience study. In the data collection used among others, interview techniques, observation, and participation and in analyzing the data classification techniques as suggested by sturttevant was used. The results of this study showed that the system of naming the types of disease consists of three types, namely by basic vocabularies basic, words with affixes, and phrase form. Basic Vocabulary forms are used when they are nouns, and generally tend to be disease suffered by community, especially skin diseases. The way of classifying the disease is based on the location of disease such as types of stomachache, inflammation on the respiratory tract, head, nose, ears, mouth and specially skin.
\end{abstract}

Keywords-- Community, Tonsawang Language, Health

\section{INTRODUCTION}

In the unity of nation and Indonesian language there are cultural diversity and regional language. Among local languages in Indonesia, one of the language in Minahasa is kept and maintained by its speaker, Tonsawang Language. Esser and Salznerplaced the Tonsawang language as one of the regional languages of Minahasa. Instead Salzner included the Tonsawang langauge as group of Minahasa Language[1]. Adriani [1] suggest that the Minahasa Language consists of five groups namely Tondano language, Tonsea language, Tombulu language, Tontemboan language, and Tonsawang language. Tonsawang language has many differences with other languages in Minahasa which concerns the phonological, morphological, syntactic, lexical, and the cultural aspects of community.

As a system, it has the regularity of the elements of language that function according to rules used to communicate. Communication will work well if the organization and the arrangement of language element variabels form a whole that can produce the meaning. In general the notion of meaning is the purpose of speaker, how to use language symbols and others and more specially the relationship between speech and the circumstances in which the utterance is used (Contextual Meaning), the elements of language those are independent of its use or its context (Lexical Meaning). In addition, there is also the meaning of language arising from the relationship between the elements of language in the larger units, such as the relationship between words and with other words in phrases or clauses (grammatical meaning). There is also a that 
connotative meaning, figurative words, and there are also meanings related to he world outside the language [2].

From the categorization of meaning as listed above it appears that the lexicon element is one of the most important elements of language. The Lexicon has at least three characteristics: 1 . The language compiler containing all the information about the meaning and use of the word in the language, 2. The word richness of a speaker, author, and a language (Vocabulary), 3. List of words that compiled like dictionaries, but with brief and practical explanations [2].

Words are one of sub-systems of languages system that interact in syntactic patterns. Words are often hierarchically related, such as grandparents, fathers, and children. As well as colors, words are organized in various systems. Words are not an isolated activity, but a part of life that goes on, a never-ending conceptualization process [3]. In language life, the quality of one's language skill is clearly depenedent on the quantity and quality of the vocabulary it has. The richer the vocabulary is, the greater the likelihood of being skilled at speaking. Nevertheless it can not be denied that quantity of vocabulary for every language society it is not the same. For the example, rice (english) it is an equivalent in Indonesian but some like padi, gabah, beras, nasi, beras ketan, and others. In this case the word rice is common in english, while in indonesian is spesific.

Thing like this also in reality exist in Minahasa Community that still maintain the local language culture, the variation of the meaning of each word is certainly not the same. Similarly the regional vocabulary local of the Tonsawang sub-ethnic with distinct the cultural and linguistic backgrounds, is different from the other subethnicies, including vocabulary related to concept of health. Tarigan argues that vhealth related vocabulary takes the form of basic vocabulary or basic words such as: joy, sorrow, pleasure, difficulty, hunger, satiety, thirst, pain, healthy, clean, dirty, alive, and dead. [4].

The vocabulary system in the concept of health that reflected in the language and culture of tonsawang community shows the different characteristics that are different from the language and other cultures of the community. Inditification of the types of disease will result in the names of disease in lexical form or word or phrase, sentence, or in short descriptive form which can be described through Tonsawang language. The problem that needs to be solves in this research revolves identifying the types of diseases. The identification generates a list of words, phrases, and sentences in a description of the various types of disease. Based on the above the problem of this research is formulated in the form of questions as follows: How does the kinds of disease name system produce list of words, phrases, and sentences in Tonsawang Society?

\section{RESEARCH METHODS}

This is qualitative research based on the eclectic approach as the combination of Semiotics Theory referred to Eco's view [5] and Hermeneutics Theory according to Ricouer . Participative observation and interview become the method of data collection, and the data analysis applied from Miles and Huberman in Interactive-Dialective Method (1992)[6].

\section{RESULT AND DISCUSSION}

\section{A. Types of Languages}

From the recorded data, both in the form of lexicon-free sentence context, and in the context of the sentence it appears that the naming of disease is rarely a single lexicon. The word pahadosan'in sickness 'or pangadosan'sakit pain' is not the name of the disease but in a state of illness caused by certain types of illness. Thus, the two words are only general without referring to a particular type of disease. Referring specifically to a particular disease in the lexical form as follows:

Pera "wound" Lembid "spot" Paso "warm"

Mahenga "coughing" Tereng "a cough dry"

Sesengen "fever" Simbalui "cancer"

Makolotin " Halihed Kumotong Ilumbidem Kuwen

Within the words, only words pera, lembid, terang, simbalui, and kuwesmurni basic word ( all is nominal), but the other only form word with added affix. The word mahenga "coughing" is the word form of hengayang got prefix ma- as function formed verbal. In Tonsawang Languages, verbal leksem has not affix meaning. Another example is halihed "be sprained". Lihed leksem never used in whatever context in structure of Tonsawang language. After affixed such as prefix ha be halihed so be a meaning be sprained. So, lihed leksem and verbal of leksems still abstract and as a basic inflective form a word (harimurti kridalaksana, 1984:114). The other example is pinosot (posot+infix-in-) to showed boil that solved. Hawosotan (posot+konfiks ha- andengan phonolgy process such as prefix /p/ which realizing alogfonisly (w).

Things like that will be more obvious in the context of a sentence. Examples in sentences (4) and (5):

(4) Na? Ammedamo what is it? I ndemahalahad

'Do not bathe in this pool because itch'

(5) Kahelemaikumbatangaiku morolahadoho

'My body feels itchy all'

In the sentence (4), it is not the pool water that itch, but the pool water causing the itching in the skin (on the body). However, the meaning of prefix is not a causative but it has. So, according to Tonsawang's view, the water in the pond contains something that can cause people to suffer from irritation. In the sentence (5), the word morolahad states the sputum of the speaker's skin. So, itchy it is the skin. The moro-prick that causes lexem lahad gives the whole itching sense (itch all). An example of the use of moro prefixes is in sentence (7) ie 'full mottle' morolembid, morowera? In the morphological process there is a phonological process that causes phonemes / $\mathrm{p} /$ to be realized allophonically [w].

In sentence (31), there is an example of a beanem imperative verb that is lexem of bean. Leksem bean never appears in the sentence because it has no special meaning. Its meaning only arises after given affix, in this case the suffix-giving the imperative meaning give !. The usage of 
the word is not polite, but according to its context, this utterance must be polite because the utterance is addressed to the healing figure in the occult. Therefore, the word is accompanied with kat o? aisebagai pemalus. The full sentence is:

Towwahadosaniwapeli?

Iosapangeleiemakiongapungansea? Naosabeanemo? Aikanyamanan

'The sick are made offerings and ask the Gods, give healing

The word o 'ai is the smoothing command to be a request (performative hedge) for beanem' give '.

\section{B. Disease Taxonomy}

Based on the data that the naming of the disease where the basic vocabulary is very limited, it can be interpreted that the naming of disease in Tonsawang society is more emphasized to the location of disease on the human body. Theocations are in the inside of the head, eyes, nose, ears, mouth along with parts therein, and bones. Such similarities are primarily diseases related to physical symptoms. Thus, the taxonomy of disease is more based on the location of the disease in human growth.

Diseases associated with the inside of the head are: mahadosikohong 'headache' (general nature)

katambulelengan 'feeling dizzy'

mangenit-ngenit 'pain throbbing in the head'

mahadosmbeta?, headache next to '(migraine)

mahadosnohatikohong'sakit urat '

Eyes:

Mahadosimbelen'sakit mata'

Pahadosanimbelen'sakit blessed eye '

Mahalalaimbelen'mata perih'

Pasambitan 'spots on the edge of the eye'

Biblical 'eye possessed little thing'

Pakembelen 'whitish in the corner of the eye'

Buras 'enlarged spots in the eye seeds'

Momeha 'reddish eyes'

Nose:

Mahadosingilung 'sore nose'

Sesengen 'nasal congestion'

Paluayan 'bleeding nose, nosebleed'

Mouth:

Mahadosimba? Ba 'sore mouth'

Paletohan 'chapped lips'

Pakowongan 'sideways'

Mahowmba? Ba 'mouth smelling'

Menitian 'wound in the mouth'

Tooth :

Mahadomba? Bang 'toothache'

Makotongkitis 'gum pain'

Mahalualang 'shake teeth'

Baumba? Bang 'decayed teeth'

Monimba? Bang 'yellowish teeth'

Ear:

Mahadostalinga 'earache

Pamengelan 'start deaf'

Lombonem 'congek'

Masuektalinga 'piercing pain in the ear'

Chest and throat:

Mahadosindada? 'chest pain'

Mahenga 'coughing'

Tereng 'dry cough'

Mahengaimeha? 'Coughing up blood'

Mahengamakorai 'slimy cough'
Stomach:

Mahadositian 'abdominal pain'

Sugah 'mules'

Sumesegah 'stomachache, mag'

Mahadosmanikam 'stomach hurt'

Masendiimeha? 'dysentery'

Mahadostu? Ditian 'cold sore'

Skin:

Mahalahad 'itching'

Morolahad 'itching all over the body'

Molomeha 'red spots'

Sisim 'ringworm'

Kolihid 'mange'

Tala? Ta 'panu'

Pedawocene 'chickenpox'

Moroladoho 'itching creeping

makotong'sakit '(about gums)

the meaning contained by the prefix of the name of the aforementioned illness is in the state as expressed by the word base.

The other prefix is maha - and moro -

Example: morolahad 'itching'

morowera? 'Injuries'

morolembid 'freckles'

mahalahad'gatal'

The meaning of prefix moro- almost the same, which is 'to have'. The difference lies in its intensity. The moro prefix implies to have much as in morowera 'wounds' and 'spotted' morolembids or superlative states as in the word morolahad 'very itchy'. The morpheme pera which is prefixed moro- becomes morowera? The result of the phonological process so that the phoneme / $\mathrm{p} /$ is realized as sound $[\mathrm{w}]$. for the prefix of the word mahalahad declare to have or produce as it is in the word and can be seen in the example of sentence (4). The other prefix is the prefix ha - as in the word halihad 'dislocated'. The data obtained for the prefix ha - is only limited to the word. The prefix forms themselves are not found much. There is also a more complex form of confix such as in the example of my rays 'an'patah'. The leksem is ru? With confix ka - - andan infiks - in -. Another example is another example is hawosotan'sudah broke'.Leksemnya posotdengan get confiks ha - an. By phonological process, sound changes occur in the initial sound of phonemes / p / realized as allophonic [w].

3. Phrase Form from the principal word mahenga as in mahengaimeha'batuk blood ', mahengamakorai' 'slimy cough'.

Different types of wounds are formed from the main word pera?

'Injuries' such as: pera? Kumotong 'wound infection'

pera? ilumembo'luka jadi sendiri'

pera? melae'luka so own'

pera? kowa? ang'luka dalam '

pera? mahowe'luka rotting '

pera? kinadep'luka cut'

pera? kinaharitan'uka scratched'

pera? behalohad'luka burn'

and many more.

Here it appears that the subcategories of painting are not specially named but only by giving a description only. This is different from other types of skin diseases that get their own names such as:

mahalahad'gatal-itch'

the 'ringworm' 


\section{kolihid 'mange' \\ tala 'ta'panu' \\ pedawosen 'chickens' \\ moroladoho'gatl-itching creeping \\ samunga 'acne' \\ samunganem'energage'}

allegedly, skin diseases like that many attacked or often suffered by people Tonsawang in the past so it needs to be given a special name. Things that are very influential in people's lives usually get special attention, whether it concerns community institutions such as naming the role in the family. In the Indonesian language there is the oldest sulung'anak 'and the easiest bungsu'anak because the role of birth order is very important in family culture according to Indonesian culture. Likewise with the types of skin diseases. Because such diseases are more dominant suffered by the community, it needs to be given a special name, not in the form of a phrase.

\section{Disease Sources and Treatment}

According to the beliefs of the Tonsawang community, the cause of a disease may originate from the supernatural as the punishment of God because of many sins or violate the prohibitions called na? Am 'tabu', from ancestors, even from other people who have malicious intentions (witches, witchcraft) by an evil shaman called tapenawoy, and can originate from the real world (natural) such as the presence of evil winds, accidents, poisonings, and others that are natural.

However, the two sources of the disease are sometimes indistinguishable by them. A person who suddenly vomits, diarrhea, dizziness, etc. is often believed to be saddled so that his treatment is done through healers called tapengundam. Based on such matters, it can be concluded that traditional medicine, whether done by tapengundam, or done with the initiative of seniri because some types of traditional medicine is known in general, is not an alternative treatment but is the main treatment.

However, traditional medicine is also often an alternative treatment. It is done if the treatment through modern medical treatment is considered no longer able to cure the illness suffered by a patient. What's more, if the doctor has given up, can no longer cure a patient as in the case- the case of a patient's late checkup to the doctor.

Other causes that traditional medicine is an alternative treatment is if the disease of a patient can not be detected by the doctor through modern medical devices, either through technological equipment, or through laboratory examination. If it has happened to such cases, the patient and or his family turned to tapengundam because the belief in the cause of disease that is personalistic began to influence it. These thoughts that affect the behavior of society so that the role of tapengundam remain large.

In addition, the cost and procedure problems also contribute to the consideration of traditional medicine as an alternative treatment. If the cost is no longer sufficient because usually the cost of modern medicine is often relatively expensive so it is not affordable by patients, then traditional medicine used as an alternative treatment. because it has to go through various stages of examination also cause many patients who can not stand, either because the newly got a turn, and because of the nature of the illness (not the emergency) that causes patients can not wait longer.

Based on the things described above as a result of interviews with informants, it can be concluded that the selection of healers by the patient and / or his family is difficult to predict where a patient will check his illness, whether he or she tapers, or to a public health officer, if the type of illness is not clear to them. Injuries due to being punctured or scratched eg, the cause is obvious, ie natural diseases. However, there is also a belief that such injuries can also be treated with traditional medicines. Other diseases such as ulcers, abdominal pain, dizziness, prolonged, often suspected that the cause or type of illness is a disease caused by supernatural forces so that the healing figure is tapengundam.

\section{Treatment}

When a patient checks his or her disease to tapengundam, it is clear that the method of treatment is the traditional way. The medicine consists of traditional medicinal herbs that are often accompanied by action (massaging and so on) and are usually accompanied by prayers or mantras known only to the tapengundam itself because the prayers or spells are pronounced in a whisper (unclear sounding).

The above mentioned that the prayers or mantras are pronounced in a whisper. However, in an interview with one tapenangoi recorded a speech in the local language that is dispel the devil. One plant species used to treat people possessed is a leaf serikaya (Annona Squamosa). Before the leaves are picked for medicinal purposes, first tapengundam utter a mantra that reads ijokokuilisangilangai's pluck it to dispel the devil's temptation '. While the leaves are rubbed on the patient (sinuang ilangai' the possessed man ') tapengundam pronounce awoiiliskuikou'saya dispels the temptation '.

How to concoct drugs that generally come from plants without mentioning the name of the material is:

1. Undambetenem, which is a medicinal material soaked in the source water in the form of fresh leaves and flowers.

2. Undamtinutu, which is dried wood to be used as medicine by mashing until smooth when used.

3. Undamkirumes, ie fresh leaves are pounded, then squeezed for use water.

4. Undamsowa? A drug that is usually chewed until smooth, then ejected to the patient.

5. Undamdinubus, which is a medicinal herb that consists of roots, and bark boiled before drinking by the priest.

6. Undambero? Boh, a fresh leaves, grown, then affixed to the sick body part.

7. Undamsoraitipego, which is a liquid in the form of plant and animal oil that is rubbed on the body part of the sick.

8. Undamliana, which is a leaf that is affixed to the affected part of the body by compression.

The eight methods of treatment as mentioned above are all nominal phrases, the endocentric phrase whose parent is noun (undam'obat '), while the modifier is the verb (betenem, tinutu, kirumus, sowaan, dandinubus) and the other is noun (baro? boh, soraitipego, danilama).

6.The way of treatment

The way of partial treatment has been put forward along with the description of how to conduct medication, that is by drinking the potion, pasted on the sick, sprayed, rubbed and some by blowing accompanied by the reading of prayer or mantra.

Other ways of treatment are as follows: 
1. Panawu-nawun, the treatment by rubbing the sick with the material while healing the healing of 'The Almighty '.

2. Manusup, a treatment by way of steam bath. Boiled water is mixed with medicinal herbs. The steam from the herb adds to the efficacy of the steam bath properties. In Malay Manado is called bakera.

3. Moneang, which is treatment with "baked" street which in Manado Malay language is called baraho. The source of fire comes from the burning of leaves and certain roots that are efficacious as a medicine. Another term for this method of treatment is bapaso 'heating up'.

4. Spray, which is the treatment by spraying some ingredients chewed until smooth to the patient.

5. Bakesen, the treatment by wrapping the language of drugs on the body part that feels pain.

6. Mawaleku, the treatment by way of medicinal ingredients that have been processed with the efficacy of cleaning the body of the patient.

7. Maniang-niangilangaiataukanalu, which is a way of treatment that is done by summoning the spirit of the patient who was taken away and captured by the 'devil'

8. Mapela? a method of treatment by using sacrificial animals to make up for the error of the patient so that the patient will recover.

9. Maisawu, which is a way of healing by sucking can or other objects embedded in the patient's body. This way is commonly used if suspected sufferers santet.

10. Mangaru, which is a way of treatment by massaging the body parts of the patient.

11. Kinareku? the treatment for people with broken bones. The trick is to massage and wrap the broken bone with the ingredients of the drug.

12. Pinatades, a treatment by punching the body of the patient with medicinal material that is considered to contain magical power.

13. Mawia-wia, the treatment given by a midwife who acts as a midwife.

The methods of treatment as described above appear to be general, if not universal in traditional societies. In traditional societies, the treatment system by rubbing the affected part accompanied by medicinal herbs, steam baths, using foliage and roots as fuel, menye, mbur the sufferer using chewed medicines, dressing with medicinal herbs, taking medicinal herbs, summoning spirits by reciting mantras, presenting animal sacrifices, sucking objects such as nails or other items normally vomited by the patient; massaging, either a massage on the part of the sick, or massaging to bring together the two ends of broken bones, pounding the body of the patient with medicinal herbs, and help in labor, all found in traditional societies everywhere.

\section{CONCLUSION}

In the Tonsawang community, traditional medicine is still widely used, both as an alternative treatment, and as a primary treatment. Decision-making to use these methods can be based on economic reasons, as well as by reason of belief in the efficacy of traditional medicine. A disease that is believed to be the cause of disease personal, traditional medicine is the main choice, while natural diseases still use alternatives, whether with traditional medicine or with modern medical treatment.

Before asking the healer, the patient and his family first try to identify the type of disease suffered. Identification is done by looking at the location of the disease. Identifying the habit produces an economic system that is the disease in the inside of the body such as abdominal pain, breathing, head, bone, and waist Outside diseases are more prevalent in skin diseases. In addition, there are various diseases of the eyes, ears, nose, and mouth.

The naming of the disease consists of lexicon (base word) especially for the type of noun such as pera? 'Wound', 'ringworm', 'ta' panu ', and so on. In addition to the lexicon, there are also formations, either in the form of prefaces like mahow, 'smelling' (about the mouth), halihed 'sprains', in the form of infix like kumotong' swell ', tinawoy' exposed santet ', a suffix like nana? Am' purulent ', and the most is in the form of conflicts such as pengadosen,' sickly ', katambulelengan' dizziness', and ilumbidem 'sign of swelling'.

In addition, there are also phrases that distinguish subcategories as pera? category 'Wound' produces the phrase pera? Mahowe 'wound rot', pera? Ilomembo 'wound itself', pera? Melae 'widespread wound', and pera? Kowa? Ang 'deep wound'. Category by location as in abdominal disease is mahadositian 'abdominal pain', mahadossisiam 'pain giving birth', and masendiimeha 'dysentery'. Locations in the mouth such as makotongkitis 'sore gums', and location in the nose paluayandaha? 'nosebleed'. The source of the disease can be a personal illness (a supernatural cause, supernatural) and can be a natural disease. However, in the unseen, natural illness is often regarded as a personal illness so the treatment is also aligned with the allegation.

The traditional system of medicine in Tonsawang society as well as in other traditional societies is done by various types of acts with medicinal ingredients, whether accompanied by mantras or not.

\section{ACKNOWLEDGMENT}

The resercher team would like to extend their gratitude to LPPM Unima for facilitating this research.

\section{REFERENCES}

[1] S. M. (dkk.), Struktur Bahasa Tonsawang. Jakarta: Pusat Pembinaan dan Pengembangan Bahasa, 1982.

[2] H. Kridalaksana, Kamus Linguistik. Jakarta: PT Gramedia, 2008

[3] H. E. (et al) Dale, Technigues of Teaching Vocabulary. California: Field of Educational Publications Incorporated, 1971.

[4] T. H. Guntur, Berbicara Sebagai Suatu Keterampilan Berbahasa. Bandung: Angkasa, 1983.

[5] U. Eco, Semiotics and the philosophy of Language. Bloomington: Indiana University Press, 1983.

[6] M. B. Miles and A. M. Huberman, Analisis data kualitatif. Jakarta: UI press, 1992. 